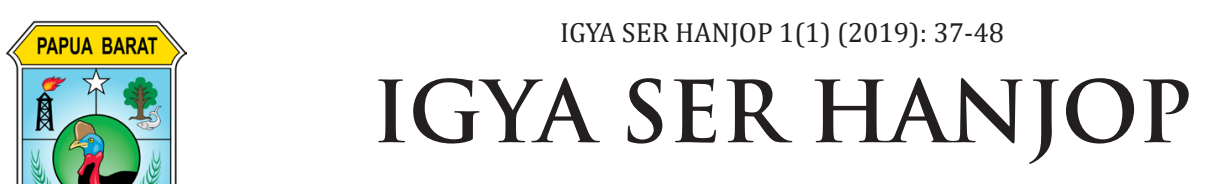

p-ISSN: 2716-0491

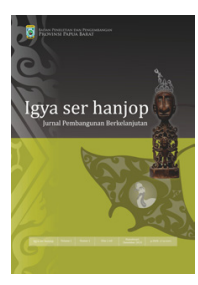

\title{
PENDEKatan Keadilan dan Keamanan \\ dalam Pembagian ManfaAt Hutan Produksi Berbasis Masyarakat Hukum Adat di Papua Barat
}

\author{
Jonni Marwa ${ }^{1 *}$, Mustofa Agung Sardjono ${ }^{2}$, Afif Ruchaemi $^{3}$, G. Simon Devung ${ }^{4}$ \\ ${ }^{1}$ Fakultas Kehutanan Universitas Papua \\ Jl. Gn. Salju, Manokwari, Papua Barat 98314. \\ 2,3,4Fakultas Kehutanan, Universitas Mulawarman \\ Jl. Gn. Kelua, Samarinda Ulu, Samarinda, Kalimantan Timur 75119.
}

Dikirim: 30 Oktober 2019; Direvisi: 28 November 2019; Disetujui: 18 Desember 2019

\begin{abstract}
The benefitsharingfrom forest resources is an approach to resolving conflicts over forest resource management that can be built from various approaches with various criteria. This study aims to identify and construct equitable and safety approach benefit sharing from production forests based on customary community. The object of this research is Mairasi tribe who live in Kaimana Regency West Papua Province which one they have petuanan rights. This study was conducted in two districts, and three villages namely Kensi, Maskur and Urisa villages. The location was selected purposively. The benefit sharing schemehas been practiced in the management of production forests in the Mairasi Tribe is recognition of petuanan right, money-based, market-based, goods-based infrastructure-based, social management based and transfer knowledge based. The construction of criteria from the perspective of the customry communityobtained 7 criteria of equity and 6 safety criteria which are then used to evaluate the performance of these forms of benefitssharing. The assessment and testing of these criteria for various forms of benefit sharing, both equity and safety approaches is sufficient category.
\end{abstract}

Keywords: benefit sharing, equity and safety approach, criteria

\section{Intisari}

Pembagian manfaat dari sumberdaya hutan merupakan pendekatan dalam penyelesaian konflik pengelolaan sumberdaya hutan yang dapat dibangun dari berbagai pendekatan dengan berbagai kriteria. Tujuan penelitian ini untuk mengidentifikasi dan mengembangkan pendekatan keadilan dan keamanan dalam pembagian manfaat sumberdaya hutan produksi berbasis masyarakat hukum adat. Suku Mairasi sebagai salah satu pemilik hak petuanan yang berdiam di wilayah Kabupaten Kaimana Papua Barat merupakan obyek dalam penelitian ini. Terdapat dua distrik, 3 kampung yakni Kampung Kensi, Maskur dan Urisa yang dipilih secara purposive sebagai lokasi penelitian. Bentuk pembagian manfaatyang dipraktekan dalam pengelolaan hutan produksi di wilayah Suku Mairasi adalah pengakuan hak petuanan, berbasis dana, berbasis pasar, berbasis barang, berbasis infrastruktur, berbasis kelola sosial dan berbasis transfer IPTEK. Pengembangan kriteria dari perspektif emik masyarakat adat menghasilkan 7 kritieria keadilan dan 6 kriteria keamanan yang kemudian digunakan untuk mengevaluasi kinerja bentu-bentuk pembagian manfaat tersebut. Penilaian dan pengujian kriteria tersebut terhadap berbagai bentuk pembagian manfaat baik pendekatan keadilan maupun keamanan berada dalam kategori cukup.

Kata Kunci: pembagian manfaat, pendekatan keadilan, dan keamanan, kriteria

\section{LATAR BELAKANG}

Pembagian manfaat dengan penegasan hak memiliki hubungan yang sangat kuat (Nawir et al., 2015). Penegasan hak memberi jaminan legal untuk mengambil keputusan terhadap investasi di dalam suatu wilayah
(Bruce \& Nielsen, 2012). Pada kondisi ini terdapat klaim teritorial, klaim sumberdaya, penguasaan fisik, dan identitas sosial budaya sehingga keberadaan hak kepemilikan mempengaruhi perilaku dan kesempatan pihak yang memilikinya (Grafton et al., 2000) dalam hal ini masyarakat pemilik hak ulayat.

\footnotetext{
* Korespondensi Penulis

Phone : +6281344340007

Email : j.marwa@unipa.ac.id
} 
Di Indonesia, ketidakadilan pembagian manfaat di hutan produksi dialami oleh masyarakat Dayak Iban Sungai Utik, Dayak Meratus di pegunungan Meratus, masyarakat Tabuyung di Muara Batang Gadis, Kabupaten Mandailing Natal, masyarakat Adat Kuntu di Kabupaten Kampar Kiri dan Masyarakat Warbiadi di Distrik Ransiki Kabupaten Manokwari Papua Barat (Rahmawati, 2013; Tokede et al., 2005; Wulan et al., 2004). Kasus yang sama ditemukan juga di beberapa negara seperti di Desa Goute dan Djemiong di Kamerun, Rwanda dan Uganda di Afrika (Baker et al., 2003; Lescuyer et al., 2012). Dalam pembagian manfaat sering kali halhal seperti perjanjian stakeholders, desain insentif, mekanisme pelaksanaan, ketentuan transparansi dan penyelesaian perselisihan tidak dilakukan secara konsisten (IUCN, 2009). Hal ini menyebabkan pembagian manfaat berjalan tidak adil dan menimbulkan ketidakamanan baik terhadap masyarakat adat maupun sumberdaya yang dikelola.

Di sisi lain, berdasarkan realita yang dijumpai di Papua Barat di dalam dan sekitar kawasan hutan tidak hanya berdiam masyarakat adat pemilik hak ulayat, namun ada komunitas lokal lain yaitu masyarakat adat yang bukan pemilik hak ulayat dan para pendatang yang juga semestinya menerima manfaat dari sumberdaya hutan. Kelompok komunitas ini mengalami kesulitan memenuhi kebutuhan dari hutan ketika dibatasi oleh pemegang izin untuk mengakses kawasan hutan. Kelompok ini hanya mendapat manfaat dari kegiatan kelola sosial yang dilakukan oleh HPH dengan rata-rata alokasi biaya hanya sebanyak 4\% per tahun (Yeny \& Innah, 2014). Dengan demikian pembagian manfaat hutan tanpa memperdulikan kepentingan komunitas lokal akan berdampak pada rasa tidak aman dan ketidakadilan bagi masyarakat. Permasalahan pembagian manfaat yang tidak memberikan rasa aman dan adil bagi masyarakat adat telah menimbulkan persepsi sosial antara lain ada ketakutan pihak luar menguasai hutan yang sama, ada kesulitan memenuhi kebutuhan dari hutan dan ada ketidakpastian masa depan atas hutan dan ada kebencian karena manfaat hutan dinikmati lebih banyak orang luar (Sardjono, 2004). Apalagi untuk wilayah Papua dengan kuatnya nilai dan pengakuan hak milik adat atas hutan dan lahan perlu menjadi perhatian serius dalam memastikan terlaksananya tata hutan yang baik (good forests governance) dan bermanfaat (benefited).

Dalam konteks pengelolaan hutan, pemerintah maupun institusi swasta (NGO) sejak awal tahun 1990-an telah mengembangkan sistem penilaian kinerja pengelolaan hutan lestari. Penilaian sustainable forest management (SFM) oleh Departemen Kehutanan mengacu kepada empat kriteria yaitu kriteria prasyarat, kriteria ekologi, kriteria produksi, dan kriteria sosial budaya dan ekonomi. Sedangkan Lembaga Ekolabale Indonesia (LEI) menggunakan 3 (tiga) kriteria, yaitu kriteria ekologi, kriteria produksi, dan kriteria sosial (Dwiprabowo \& Suwarno, 2013). Organization for Economic Corporation and Development (OECD), mengembangkan prinsip dasar Good Corparet Governance adalah: kewajaran, akuntabilitas, transparansi, dan responsibilitas (Abu-Tapanjeh, 2006).

Dalam analisis pembagian manfaat untuk skema perdagangan karbon the Governance of Forest Initiative (GFI) mengembangkan 5 prinsip terkait good governance (Brito et al., 2009), yaitu: transparansi, partisipasi, akuntabilitas, koordinasi dan kapasitas dan 94 Kriteria. Semua kriteria dan indikator yang telah dikembangkan masih bersifat umum dan belum terintegrasi dengan prinsip-prinsip keadilan dan keamanan dalam satu unit manajemen hutan khususnya dalam pembagian manfaat terhadap sumberdaya hutan.Oleh karena studi ini dilakukan dengan tujuan untuk mengidentifikasi dan mengembangkan pendekatan keadilan dan keamanan dalam pembagian manfaat sumberdaya hutan produksi berbasis masyarakat hukum adat.

\section{Metode}

\section{a) Tempat dan Waktu Penelitian}

Penelitian ini dilakukan di Kampung Kensi dan Maskur Distrik/Kecamatan Teluk Arguni dan Kampung Urisa Distrik/Kecamatan Arguni Bawah Kabupaten Kaimana Provinsi Papua Barat. Waktu penelitian dilaksanakan selama bulan Juli - September 2017.

\section{b) Metode Pengumpulan Data}

Kampung/Desa yang dipilih pada masing-masing distrik dilakukan secara sengaja (purposive sampling) dengan alasan: 


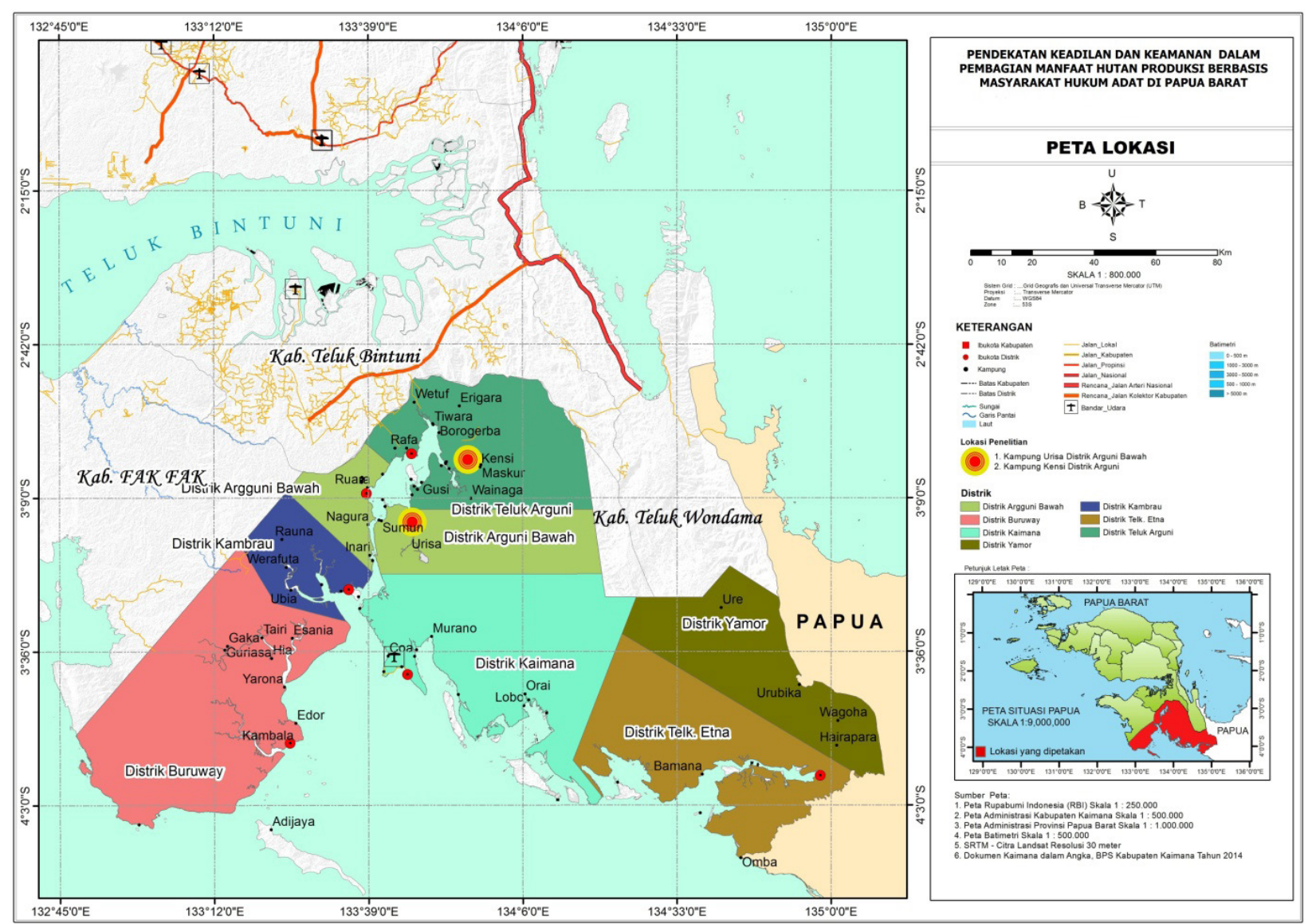

Gambar 1. Lokasi Penelitian di Kampung Kensi, Maskur dan Urisa Kabupaten Kaimana

(a) kampung/desa yang ada tidak semua masyarakatnya menerima pembayaran kompensasi hak ulayat; (b) tidak semua kampung/desa di wilayah tersebut hak ulayatnya masuk dalam areal konsesi IUPHHK; (c) kampung-kampung tersebut terdiri dari beberapa suku yang berbeda, sehingga sesuai sebagai kasus yang dipelajari untuk mencapai tujuan penelitian.

\section{c) Penetapan Informan sebagai Responden}

Penelitian ini dirancang menggunakan 3 (tiga) klasifikasi sumber informasi/informan sebagai responden, yakni: Informan kunci (Key informants/ KI) sebanyak 9 orang.Informan Kasus (Case informants/CI) sebanyak11 orang. Selain itu, informan kasus juga dipilih dari masyarakat lokal yang tidak memiliki hak ulayat termasuk kelompok migran dan perempuan. Jumlah responden dipilih sebanyak 9 KK.Informan berkesempatan (Opportunity informants/OI), sebanyak 3 orang.

\section{d) Metode Analisis}

Analisis data dilakukan dengan metode yang berbeda sesuai dengan tujuan penelitian sebagai berikut: analisis penilaian subyektif, yakni untuk mengetahui perspektif emik dalam menilai pembagian manfaat. 1).Penilaian subyektif menggunakan kriteria yang berasal dari sudut pandang subjek (emik). Setiap informan akan memberikan kriteria yang dianggap penting atau perlu digunakan dalam mengukur skema pembagian manfaat yang adil dan aman. Kriteria yang diidentifikasi dikelompokan dan diuji tingkat kepentingannya dengan cara diskoring. Kisaran nilai skor dari 1 (satu) sampai dengan 5 (lima). Di mana skor 1 (sangat tidak penting), 2 (Tidak penting), 3 (cukup penting), 4 (penting), 5 (sangat penting) (Golar, 2007). Kriteria yang memiliki nilai penting sampai sangat penting ditetapkan sebagai kriteria pembagian manfaat yang adil dan aman bagi masyarakat adat. 2). Analisis persepsi stakeholders, dilakukan dengan pendekatan skala Likert. 3) pendekatan prinsip pembagian manfaat yang adil dan aman bagi Masyarakat Adat. Metode ini digunakan secara khusus untuk menilai aktifitas pembagian manfaat yang adil dan aman bagi 
masyarakat adat berdasarkan perspektif emik (subjek) masyarakat adat. Dalam penilaian subjektif digunakan kriteria yang berasal dari sudut pandang subjek (emik). Setiap informan akan memberikan kriteria yang dianggap penting atau perlu digunakan dalam mengukur adil tidaknya dan aman tidaknya aktivitas pembagian manfaat. Dengan metode pengulangan kata informan akan menghasilkan kriteria-kriteria yang adil. Kriteria tersebut dikombinasikan dengan prinsip-prinsip pembagian manfaat yang adil (Essam Yassin Mohammed, 2011; Michelle Maiese, 2013; Törnblom \& Vermunt, 2007; Wagstaff, 1994). Selanjutnya dilakukan penilaian terhadap kriteria berdasarkan indikator-indikatornya masing-masing. Tiap indikator diukur skala intensitasnya dengan menggunakan 3 (tiga) kategori yaitu nilai 5 (baik), nilai 3 (cukup), nilai 1 (buruk). Untuk menetapkan nilai yang akan diberikan didasarkan pada pengukur (verifier) yang dapat diterapkan. Penentuan 3 kategori mengadopsi Lembaga Ekolabel Indonesia untuk penentuan kriteria dan indikator pengelolaan hutan berbasis masyarakat lestari (LEI, 2006).

Kecenderungan terhadap pembagian manfaat yang adil dan aman ditentukan berdasarkan skala intensitas indikator dari masing-masing kriteria. Karena pada setiap kriteria dan indikator memiliki bobot yang sama, maka nilai total pencapaian pembagian manfaat yang adil diperoleh melalui total penjumlahan dari seluruh nilai indikator yang digunakan. Adapun penentuan kecenderungan pembagian manfaat yang adil adalah sebagai berikut: Jumlah nilai baik berkisar 3.68 - 5.00, jumlah nilai sedang berkisar dari $2.34-3.67$ dan jumlah nilai jelek berkisar dari 1 - 2.33.4). Analisis statistik deskriptif digunakan untuk menguji pengaruh kriteria prinsip keadilan dan kriteria prinsip keamanan pada setiap bentuk pembagian manfaat dengan menggunakan Uji t satu sampel. Hipotesis yang diajukan hipotesis nol (Ho) "Bentuk pembagian manfaat bagi Suku Mairasi memiliki nilai lebih besar atau sama dengan ( $\geq$ ) 3.68. Sedangkan hipotesis alternatif berbunyi "Bentuk pembagian manfaat bagi Suku Mairasi lebih kecil dari atau sama dengan ( $\leq$ ) 3.68. Tingkat signifikansi atau nilai alfa pada penelitian ini ditetapkan sebesar $5 \%$ atau 0,05 .

\section{HASIL DAN PEMBaHASAN}

\section{A. Identifkasi Pembagian Manfaat pada Masyarakat Hukum Adat Suku Mairasi}

Dalam pengelolaan hutan produksi di Papua Barat khususnya di wilayah Kabupaten Kaimana dimana berdiam Suku Mairasi terdapat beberapa bentuk pembagian manfaat sebagaimana dijelaskan di bawah ini.

\section{1) Pengakuan Hak Petuanan}

Skema pengakuan hak bagi Suku Mairasi disebut "hak petuanan". Pengakuan terhadap hak ulayat Suku Mairasi merupakan bentuk manfaat yang dirasakan setelah kurang lebih 3 (tiga) dekade pengakuan itu tidak didapat baik dari pemerintah maupun korporasi yang mengelola hutan di wilayah tersebut. Legalitas pengakuan ini muncul setelah terbit UndangUndang Otonomi Khusus Papua pada 2001 dengan beberapa produk turunannya sampai pada surat keputusan Gubernur Papua Barat Nomor 5 Tahun 2017 tentang Kompensasi Kayu Bagi Masyarakat Hukum Adat di Papuaa Barat.

\section{2) Pembagian Manfaat Berbasis Dana}

Bentuk bagi manfaat berbasis dana yang dilakukan di wilayah adat Suku Mairasi terdiri dari kompensasi dan ganti rugi tanaman pala karena hutan wilayah tersebut juga didominasi oleh pohon-pohon pala namun biaya ganti rugi diatur dalam perda Bupati Kaimana. Aliran manfaat terbesar dimiliki oleh pemilik hak ulayat dibandingkan bukan pemilik hak ulayat dan pendatang, sehingga ada sifat ekslusif dari skema berbasis dana. Sifat ekslusif ini didasarkan pada hak yang melekat pada pemilik hak ulayat sebagai owner (Schlager \& Ostrom, 1992). Sedangkan masyarakat yang bukan pemilik hak ulayat hanya merasakan manfaat dari retribusi kampung, pembangunan sarana ibadah dan sarana fisik lainnya. Hal ini menunjukkan bahwa hak kepemilikan akan mempengaruhi perilaku dan kesempatan pihak yang memilikinya (Grafton et al., 2000). Nilai kompensasi yang diterima dalam bentuk uang berkisar dari Rp. 21.589.500 - Rp. 843.413.200.

Tinggi rendahnya nilai kompensasi sangat ditergantung pada jumlah volume produksi. Produksi rata-rata pada wilayah adat 
Tabel 1.

Volume Kayu dan Nilai Kompensasi Hutan Produksi dari Hak Ulayat Suku Mairasi

\begin{tabular}{lrr}
\hline $\begin{array}{l}\text { Parameter } \\
\text { (parameter) }\end{array}$ & $\begin{array}{r}\text { Volume Kayu (m }{ }^{3} \text { ) } \\
\text { (Wood volume, } \mathbf{~}^{3} \text { ) }\end{array}$ & $\begin{array}{r}\text { Nilai Kompensasi (Rp) } \\
\text { (Compensation Value, IDR) }\end{array}$ \\
\hline Minimal (minimal) & 143,93 & 21.589 .500 \\
Maksimum ( Maximum) & $21.085,33$ & 843.413 .200 \\
Rata-Rata ( Average) & $7.461,76$ & 326.868 .233 \\
Standar deviasi (Standard deviation) & $11.809,21$ & 449.803 .973 \\
\hline
\end{tabular}

yakni $7.461,76 \mathrm{~m}^{3}$. Dengan nilai kompensasi yang diterima pemilik hak ulayat rata-rata $326.868 .233 \mathrm{~m}^{3}$ per tahun. Bila dilihat dari nilai maksimum produksi kayu pada wilayah Suku Mairasi dengan jumlah produksi 21.085,33 $\mathrm{m}^{3}$, tetapi nilai kompensasinya hanya $\mathrm{Rp}$. $843,413,200$.

\section{3) Pembagian Manfaat Berbasis Pasar}

Pada skema berbasis pasar terdapat pasar insidentil dengan sistem jual beli (transaksi pasar) dan sistem barter. Skema berbasis pasar merupakan upaya pemberdayaan masyarakat di sekitar hutan dimana pihak perusahaan sebagai konsumen yang menyediakan uang cash, sedangkan masyarakatsebagai produsen yang menyediakan hasil-hasil usaha tani untuk perjualbelikan. Namun hasil-hasil usaha tani yang diperjualbelikan tidak dapat disediakan secara kontinyu oleh masyarakat sekitar, sehingga kebayakan perusahaan membeli dari luar. Dengan demikian uang yang beredar perusahaan mengalami "kebocoran" ke luar wilayah konsesi. Skema ini dapat diakses oleh semua kelompok masyarakat bukan hanya pemilik hak ulayat, tetapi juga kelompok masyarakat lainnya.

\section{4) Pembagian Manfaat Berbasis Barang}

Sulitnya aksesibiltas ke ibukota kabupaten menyebabkan masyarakat di wilayah-wilayah terpencil seperti Kensi dan Maskur, serta Kampung Urisa membeli beberapa barang kebutuhan sehari-hari pada koperasi dan pasar yang diadakan perusahaan. Pembelian barangbarang kebutuhan sehari sering juga dilakukan dengan sistem panjar khusus bagi masyarakat yang memiliki hak ulayat. Sulitnya memperoleh uang tunai di wilayah kampung membuat masyarakat memilih untuk melakukan sistem panjar. Hal ini berdampak pada jumlah uang kompensasi yang diterima oleh petuanan dimana besaran uang terlihat sangat kecil karena telah dipotong panjar.

Masyarakat pemilik hak ulayat tidak semuanya memilih pembayaran kompensasi berbasis uang, terdapat beberapa orang yang memilih untuk dibayar dalam bentuk barang atau sarana perekonomian rumah tangga yang sulit diperoleh. Misalnya barang-barang yang diminta masyarakat Kampung Urisa antara lain motor tempel $40 \mathrm{PK}$, mesin chain saw, sepede motor merk vixon yang diestimasi nilai ekonominya sebesar Rp. 218.000.000,-. Jenisjenis barang tersebut secara tertulis dimasukan dalam surat perjanjian kerjasama dalam hal pengelolaan IUPHHK PT. Irma Sulindo dengan pemilik hak ulayat.

5) Pembagian Manfaat Berbasis Infrastruktur Secara sosial pembangunan infrastruktur jalan dan jembatan memberikan pengaruh terhadap efisiensi waktu dan biaya perjalanan masyarakat ke dan dari pusat-pusat pelayanan ekonomi seperti pasar, dan perbankan, pusat pelayanan kesehatan, pusat pelayanan pendidikan dan pusat pelayanan sosial lainnya. Pembangunan infrastruktur dilakukan oleh pihak perusahaan. Pembangunan infrastruktur dasar seperti jalan induk, jalan cabang dan jalan sarad merupakan solusi bagi masalah kemiskinan. Infrastruktur jalan memiliki peran positif terhadap pertumbuhan ekonomi dengan jangka pendek menciptakan lapangan kerja sektor konstruksi dan jangka menengah maupun jangka panjang akan mendukung peningkatan efisiensi dan produktivits sektorsektor terkait (Ja'far, 2007). Karena itu, skema pembagian manfaat berbasis infrastruktur merupakan manfaat yang diperoleh masyarakat adat dan masyarakat lokal lainnya dari kegiatan 
pembangunan infrastruktur tingkat kabupaten, distrik dan kampung.

\section{6) Pembagian Manfaat Berbasis Kelola Sosial}

Kelola sosial merupakan praktek pembagian manfaat sumberdaya hutan yang diterima masyarakat lokal atau pemilik hak ulayat terkait dengan kegiatan-kegiatan sosial yang dilakukan dalam kampung atau distrik dan hal ini merupakan salah satu kewajiban perusahaan. Manfaat ini diterima masyarakat dalam bentuk barang dan digunakan untuk kepentingan umum. Misalnya masyarakat Adat Mairasi di Kampung Urisa meminta bantuan pembangunan gereja berupa : Atap Seng, Seng gelombang, Tehel $30 \times 30 \mathrm{~cm}$, Paku seng 2 dos dan paku campuran $20 \mathrm{~kg}$, Pintu, jendela, dan mimbar utama serta mimbar cadangan. Bantuan sosial bagi masyarakt Mairasi di Kensi dan Maskur juga dilakukan oleh perusahaan misalanya transportasi motor tempel untuk membantu masyarakat dalam menjual hasil hutan/kebun berupa biji dan bunga pala ke kota. Bagi beberapa siswa diberikan bantuan sekolah berupa beasiswa. Bantuan dalam mendirikan gereja berupa semen 200 sak dan uang Rp. 25 juta rupiah.

Tabel 2.

Hasil Identifikasi Kriteria Pendekatan Keadilan dan Keamana berdasarkan Persepsi Masyarakat Adat Mairasi

\begin{tabular}{|c|c|c|c|c|}
\hline No & $\begin{array}{l}\text { Kriteria Keadilan } \\
\text { (Equitable criteria) }\end{array}$ & $\begin{array}{c}\text { Rata-Rata } \\
\text { Skoring } \\
\text { (average } \\
\text { Scoring) }\end{array}$ & $\begin{array}{c}\text { Kriteria Keamanan } \\
\text { (Safety criteria) }\end{array}$ & $\begin{array}{c}\text { Rata-Rata } \\
\text { Skoring } \\
\text { (average } \\
\text { scoring) }\end{array}$ \\
\hline
\end{tabular}

\begin{tabular}{|c|c|c|c|c|}
\hline 1 & $\begin{array}{l}\text { Adanya Kebebasan bagi mas- } \\
\text { yarakat adat (Free acces for } \\
\text { customary community) }\end{array}$ & 3,20 & $\begin{array}{l}\text { Perlindungan hak masyarakat adat (Pro- } \\
\text { tection customary community right) }\end{array}$ & 4,5 \\
\hline 2 & Keadilan (Equity) & 4,80 & $\begin{array}{l}\text { Kemampuan beradaptasi terhadap } \\
\text { perubahan sosial (adaptability to social } \\
\text { change) }\end{array}$ & 3,80 \\
\hline 3 & $\begin{array}{l}\text { Keberpihakan kepada yang } \\
\text { miskin (Pro poor) }\end{array}$ & 4,50 & Partisipasi (Participation) & 4,55 \\
\hline 4 & Transparansi (Transparancy) & 4,20 & $\begin{array}{l}\text { Adanya penyelesaian perselisihan (prob- } \\
\text { lem solving) }\end{array}$ & 3,78 \\
\hline 5 & $\begin{array}{l}\text { Adanya Tambahan Pendapa- } \\
\tan (\text { Additional income) }\end{array}$ & 4,35 & $\begin{array}{l}\text { Adanya informasi yang transparan dan } \\
\text { akuntabel (transparent and accountable } \\
\text { information) }\end{array}$ & 3,90 \\
\hline 6 & Kesetaraan (Equality) & 4,00 & $\begin{array}{l}\text { Jaminan inter dan antar generasi (Safety } \\
\text { for inter and between generations) }\end{array}$ & 4,80 \\
\hline 7 & $\begin{array}{l}\text { Sesuai dengan ketentuan hu- } \\
\text { kum yang berlaku (Applicable } \\
\text { legal provision) }\end{array}$ & 3,50 & $\begin{array}{l}\text { Kelestarian sumberdaya hutan (sustain- } \\
\text { able forest resources) }\end{array}$ & 4,30 \\
\hline 8 & $\begin{array}{l}\text { Ada denda bagi yang melang- } \\
\text { gar (There are penalties for } \\
\text { those who violate) }\end{array}$ & 3,58 & $\begin{array}{l}\text { Akses terhadap sumberdaya hutan (Ac- } \\
\text { cess to forest resources) }\end{array}$ & 4,75 \\
\hline 9 & $\begin{array}{l}\text { Ada Jaminan terhadap HAM } \\
\text { (Human rights guarantees) }\end{array}$ & 3,60 & $\begin{array}{l}\text { Kelembagaan adat yang kuat } \\
\text { (Strengtehn Customary institution) }\end{array}$ & 3,85 \\
\hline 10 & $\begin{array}{l}\text { Berbasis Kebutuhan (Need } \\
\text { Based) }\end{array}$ & 4,70 & Modal Sosial (Social capital) & 4,30 \\
\hline 11 & Berbasis Hak ( Right based) & 4,90 & $\begin{array}{l}\text { Adanya penegakan hukum ( law enforce- } \\
\text { ment) }\end{array}$ & 3,00 \\
\hline
\end{tabular}

Keterangan :

1 (sangat tidak penting), 2 (tidak Penting), 3 (Cukup penting), 4( Penting), 5 (Sangat penting) 
Tabel 3.

Skor Kriteria Pendekatan Keadilan pada Pembagian Manfaat

\begin{tabular}{lccccccc}
\hline & \multicolumn{7}{c}{$\begin{array}{c}\text { Rata-Rata Skor Bentuk Pembagian Manfaat } \\
\text { (average scoring in benefit sharing scheme) }\end{array}$} \\
\cline { 2 - 8 } Kriteria (criteria) & $\begin{array}{c}\text { Pengakuan } \\
\text { Hak (recog- } \\
\text { nice custom- } \\
\text { ary right) }\end{array}$ & $\begin{array}{c}\text { Basis } \\
\text { Uang } \\
\text { (money } \\
\text { based) }\end{array}$ & $\begin{array}{c}\text { Basis } \\
\text { Pasar } \\
\text { (market } \\
\text { base) }\end{array}$ & $\begin{array}{c}\text { Basis } \\
\text { Barang } \\
\text { (goods } \\
\text { based) }\end{array}$ & $\begin{array}{c}\text { Basis In- } \\
\text { frastruktur } \\
\text { (Infra- } \\
\text { structure } \\
\text { based) }\end{array}$ & $\begin{array}{c}\text { Basis } \\
\text { Kelola } \\
\text { Sosial } \\
\text { (Social } \\
\text { based) }\end{array}$ & $\begin{array}{c}\text { Basis IPTEK } \\
\text { (Transfer } \\
\text { based) }\end{array}$ \\
\hline Kesetaraan (equality) & 4,20 & 3,00 & 3,00 & 2,90 & 3,00 & 3,00 & 2,30 \\
\hline Keadilan (equity) & 4,00 & 3,00 & 3,00 & 3,50 & 3,00 & 3,00 & 2,25 \\
\hline $\begin{array}{l}\text { Berbasis Hak (right based) } \\
\text { Keberpihakan kepada yang }\end{array}$ & 5,00 & 5,00 & 2,00 & 5,00 & 2,00 & 2,30 & 1,00 \\
\hline $\begin{array}{l}\text { miskin (pro poor) } \\
\text { Transparansi (Transparancy) }\end{array}$ & 3,20 & 3,00 & 4,00 & 4,00 & 2,50 & 2,10 & 1,00 \\
\hline $\begin{array}{l}\text { Adanya tambahan } \\
\text { pendapatan (Additional } \\
\text { income) }\end{array}$ & 3,00 & 3,80 & 5,00 & 4,50 & 2,00 & 3,00 & 3,20 \\
\hline $\begin{array}{l}\text { Berbasis Kebutuhan (Need } \\
\text { based) }\end{array}$ & 2,30 & 2,00 & 2,30 & 5,00 & 3,00 & 2,00 & 1,00 \\
\hline $\begin{array}{l}\text { Rerata Skor (everage } \\
\text { scoring) }\end{array}$ & 3,40 & 3,18 & 3,18 & 3,84 & 2,50 & 2,70 & 1,94 \\
\hline
\end{tabular}

7) Pembagian Manfaat Berbasis Transfer Ilmu Pengetahuan dan Teknologi

Pembagian manfaat ini sebatas mempekerjakan masyarakatadatsebagai buruh kasar dan tenaga harian lepas dalam kegiatankegiatan pengelolaan hutan. Dari jumlah tenaga kerja yang dikerjakan 77,42\% merupakan karyawan dengan status pengupahan bulanan, dan 22,58\% merupakan karyawan borongan. Sejumlah karyawan sebagaimana disebutkan di atas bukan masyarakat Mairasi, sehingga tidak berkotribusi terhadap ekonomi masyararakat. Pihak perusahaan hanya melaksanakan pendidikan lingkungan dan pelatihan ketrampilan yang bersifat insidentil sehingga belum memberikan dampak positif bagi peningkatan ketrampilan dan pengetahuan bagi masyarakat untuk mengakses lapangan kerja di perusahaan.

\section{B. Penetapan Kriteria dalam Prinsip Keadilan dan Keamanan pada Suku Mairasi}

Pembagian manfaat yang teridentifikasi dalam praktek pengusahaan sumberdaya hutan produksi dalam wilayah adat Suku Mairasi di Kampung Kensi, Maskur dan Urisa memiliki kelebihan dan kelemahan. Evaluasi dilakukan dengan dua pendekatan/prinsip yaitu pendekatan keadilan dan keamanan. Hasil identfikasi kriteria pendekatan keadilan dan keamanan yang diperoleh dari masyarakat adat di wilayah Suku Mairasi sebagaimana disajikan pada Tabel 2.

Berdasarkan hasil indentifikasi pendekatan keadilan dan keamanan masingmasing terdapat 11 kriteria dari perspektif masyarakat adat.Selanjutnya dilakukan penilaian berdasarkan persepsi untuk menilai tingkat kepentingan dari masing-masing kriteria sehingga diperoleh 7 kriteria keadilan dan 6 kriteria keamanan. Kriteria yang memiliki rata-rata diatas 4 atau masuk kategori penting yang terpilih menjadi pendekatan keadilan dan keamanan untuk menilai bentuk-bentuk pembagian manfaat.

Tabel 3 menunjukkan bahwa hanya pembagian manfaat berbasis barang yang memiliki nilai baik $(3,84)$. Sebaliknya terdapat satu bentuk pembagian manfaat yang jelek atau buruk yakni bentuk transfer teknologi dan pengetahuan $(1,94)$. Sedangkan bentuk pembagian manfaat lainnya memiliki nilai cukup dengan kisaran dari 2,7-3,40. 
Tabel 4.

Rekapitulasi Hasil Uji t Pendekatan Keadilan pada setiap bentuk Pembagian Manfaat

\begin{tabular}{|c|c|c|c|c|c|}
\hline \multirow{2}{*}{$\begin{array}{l}\text { Bentuk Pembagian Manfaat } \\
\text { (benefit sharing scheme) }\end{array}$} & \multirow{2}{*}{$\begin{array}{l}\text { Rata-rata } \\
\text { (Mean) }\end{array}$} & \multirow{2}{*}{$\begin{array}{c}\text { Standar deviasi } \\
\text { (Standard } \\
\text { deviation) }\end{array}$} & \multirow{2}{*}{$n$} & \multicolumn{2}{|c|}{ Uji t (t test) } \\
\hline & & & & Thit & $\mathrm{T}$ tabel $(\alpha, \mathrm{db})$ \\
\hline $\begin{array}{l}\text { Pengakuan Hak Ulayat } \\
\text { (recognice customary right }\end{array}$ & 3,095 & 1,34 & 21 & $-6,52328$ & 2,085963 \\
\hline Berbasis Uang (money based) & 3,190 & 1,08 & 21 & $-7,69288$ & 2,085963 \\
\hline Berbasis Pasar (maket based) & 2,667 & 1,59 & 21 & $-6,5561$ & 2,085963 \\
\hline $\begin{array}{l}\text { Berbasis Infrastruktur (Infrastructure } \\
\text { based) }\end{array}$ & 3,022 & 1,43 & 21 & $-6,17363$ & 2,085963 \\
\hline $\begin{array}{l}\text { Berbasis Kelola Sosial } \\
\text { (Social based) }\end{array}$ & 2,399 & 1,30 & 21 & $-8,95287$ & 2,085963 \\
\hline $\begin{array}{l}\text { Berbasis Transfer Iptek } \\
\text { (Transfer knowledge based) }\end{array}$ & 2,155 & 1,38 & 21 & $-9,21572$ & 2,085963 \\
\hline
\end{tabular}

\section{Pengujian Kriteria Pendekatan Keadilan dengan Berbagai Ben- tuk Pembagian Manfaat Hutan Produksi}

Uji terhadap tujuh kriteria pendekatan keadilan dalam pembagian manfaat dilakukan dengan uji t. Berdasarkan derajat bebas 20 (n1) dan taraf kesalahan $5 \%$ untuk uji satu pihak $t$ tabelnya adalah 2,085. Artinya ternyata thitung jauh pada daerah penerimaan Ha, oleh karena itu maka Ho ditolak dan Ha diterima. Hal ini berlaku untuk keseluruhan bentuk pembagian manfaat. Jadi pernyataan bahwa skema pembagian manfaat berbasis pendekatan keadilan bagi Suku Mairasi lebih besar atau sama dengan 3,68 atau masuk dalam kategori baik ditolak. Hal tersebut menggambarkan bahwa seluruh bentuk bagi manfaat berada dalam kisaran cukup atau sedang. Namun bila dilihat dari sebaran nilai rata-rata terdapat satu skema yang masuk dalam kategori jelek atau rendah yakni skema berbasis transfer pengetahuan dan teknologi $(2,16)$. Skema berbasis transfer pengetahuan dan teknologi tidak banyak menyentuh kebutuhan dan harapan masyarakat di dalam dan sekitar hutan. Rekruting tenaga kerja tetap dilakukan sangat selektif sehingga sulit bagi masyarakat lokal untuk mengakses kesempatan tersebut. Disisi lain upaya pelatihan maupun pembinaan masyarakat dengan berbagai ketrampilan sangat jarang dilakukan, sehingga makin membatasai akses ke lapangan kerja. Selain tingkat pendidikan masyarakat rendah (ratarata tamat sekolah dasar), tetapi disisi lain ada ketidaktegasan upaya pemberdayaan masyarakatadat. Tidak ada inisiatif pihak-pihak luar untuk berbagi dan mendorong berjalannya proses transfer pengetahuan. Dengan demikian proses learning by doing untuk menciptakan keunggulan komparatif pada masyarakat adata tidak terbangun.

\section{Pembagian Manfaat Berdasarkan Pendekatan Keamanan}

Pembagian manfaat dari sumberdaya hutan bagi masyarakat adat Mairasidinilai jugaberdasarkanpendekatankeamanan.

Hasil penilaian terhadap prinsip keamanan berkisar antara 1,58-3,56. Sebagian besar bentuk pembagian manfaat masuk kategori cukup, hanya satu bentuk bagi manfaat yang masuk kategori jelek yakni transfer IPTEK. Bentuk pembagian manfaat berupa pengakuan hak memberikan dampak terhadap tingkat kohesifitas yang tinggi karena koneksikoneksi kekeluargaan dan kesukuan, sehingga mendorong pembentukan jaringan rasa percaya (networks of trust) yang dibangun dalam batas-batas keluarga, marga, dan suku.

Masyarakat adat pemilik hak ulayat memiliki kesempatan untuk berpatisipasi mulai dari manajemen, perencanaan, implementasi dan distribusi manfaat. Namun demikian partisipasi itu terjadi karena adanya faktor pendorong yakni uang, bukan secara 
spontan. Dari sisi akses terhadap sumberdaya, masyarakat adat masih memiliki akses ke dalam kawasan hutan yang menjadi wilayah kelola HPH, tetapi kegiatan pemungutan kayu dan HHBK dilakukan untuk keperluan yang bersifat subsisten, tidak untuk tujuan komersil. Lokasi pemungutan HHBK juga sudah berada jauh dari wilayah kampung.

Pembagian manfaat dalam bentuk uang hanya diperoleh oleh masyarakat ada pemilik hak ulayat. Hanya saja dana tersebut tidak dipakai untuk keberlanjutan ekonomi rumah tangga karena sebagian besar pemilik hak ulayat tidak memiliki tabungan keluarga. Selain itu, ada pemilik hak ulayat yang melakukan sistem panjar uang kompensasi kayu sehingga pada saat pembayaran kompensasi jumlah yang diterima terlalu kecil sehingga berdampak kepada pemenuhan kebutuhan hidup dan keberlanjutan usaha produktif.

\section{E. Pengujian Kriteria Pendekatan Keamanan dengan Berbagai Ben- tuk Pembagian Manfaat Hutan Produksi}

Uji terhadap enam Kriteria pendekatan keamanan dalam pembagian manfaat dilakukan pada masing-masing skema bagi manfaat dengan menggunakan parameter-parameter statistik yakni uji t.

Tabel 6 memberikan gambaran bahwa dengan derajat bebas 23 (n-1) dan taraf kesalahan $5 \%$ untuk uji satu pihak t tabelnya adalah 1,713. Ternyata $t$ hitung jauh pada daerah penerimaan Ho, oleh karena itu maka Ho ditolak dan Ha diterima. Hal ini berlaku untuk keseluruhan skema pembagian manfaat. Jadi pernyataan bahwa skema pembagian manfaat berdasarkan prinsip keamanan bagi Suku Mairasi lebih besar atau sama dengan 3.68 atau masuk dalam kategori baik ditolak, karena

Tabel 5.

Skor Kriteria Pendekatan Keamana pada Pembagian Manfaat

\begin{tabular}{|c|c|c|c|c|c|c|c|}
\hline \multirow[b]{2}{*}{ Kriteria (criteria) } & \multicolumn{6}{|c|}{ Skor bentuk Pembagian Manfaat } & \multirow[b]{2}{*}{$\begin{array}{l}\text { Basis } \\
\text { trasnfer } \\
\text { IPTEK } \\
\text { (Transfer } \\
\text { knowledge } \\
\text { based) }\end{array}$} \\
\hline & $\begin{array}{l}\text { Pengakuan } \\
\text { Hak (recognice } \\
\text { customary } \\
\text { right) }\end{array}$ & $\begin{array}{c}\text { Basis Uang } \\
\text { (money } \\
\text { based) }\end{array}$ & $\begin{array}{c}\text { Basis Pasar } \\
\text { (market } \\
\text { based) }\end{array}$ & $\begin{array}{l}\text { Basis } \\
\text { Barang } \\
\text { (goods } \\
\text { based) }\end{array}$ & $\begin{array}{c}\text { Basis } \\
\text { Infrastruktur } \\
\text { (Infrastructure } \\
\text { based) }\end{array}$ & $\begin{array}{c}\text { Basis Kelola } \\
\text { Sosial (Social } \\
\text { based) }\end{array}$ & \\
\hline $\begin{array}{l}\text { Perlindungan hak } \\
\text { masyarakat adat } \\
\text { (Protection } \\
\text { customary } \\
\text { community right) }\end{array}$ & 4,30 & 3,50 & 2,30 & 4,50 & 2,40 & 3,00 & 2,24 \\
\hline $\begin{array}{l}\text { Jaminan inter dan } \\
\text { antar generasi } \\
\text { (Safety for inter and } \\
\text { between generations) }\end{array}$ & 2,50 & 3,00 & 3,15 & 4,50 & 2,30 & 3,00 & 1,53 \\
\hline $\begin{array}{l}\text { Kelestarian } \\
\text { sumberdaya hutan } \\
\text { (sustainable forest } \\
\text { resources) }\end{array}$ & 2,00 & 2,10 & 1,90 & 3,25 & 3,00 & 2,00 & 1,67 \\
\hline $\begin{array}{l}\text { Akses terhadap } \\
\text { sumberdaya hutan } \\
\text { (access to forest } \\
\text { resources) }\end{array}$ & 2,50 & 3,45 & 2,60 & 3,00 & 2,67 & 3,00 & 1,25 \\
\hline $\begin{array}{l}\text { Partisipasi } \\
\text { (participation) }\end{array}$ & 2,50 & 2,30 & 3,10 & 3,10 & 2,70 & 2,40 & 1,80 \\
\hline $\begin{array}{l}\text { Modal Sosial (Social } \\
\text { capital) }\end{array}$ & 3,45 & 3,65 & 5,00 & 3,00 & 2,45 & 2,10 & 1,00 \\
\hline Rerata (average) & 2.88 & 3.00 & 3.01 & 3.56 & 2.25 & 2.58 & 1.58 \\
\hline
\end{tabular}


Tabel 6.

Rekapitulasi Hasil Uji t Prinsip Keamanan terhadap Bentuk Pembagian Manfaat

\begin{tabular}{|c|c|c|c|c|c|}
\hline \multirow{2}{*}{$\begin{array}{l}\text { Bentuk Pembagian Manfaat } \\
\text { ( Benefit Sharing Scheme) }\end{array}$} & \multirow{2}{*}{$\begin{array}{l}\text { Rata-Rata } \\
\text { (Mean) }\end{array}$} & \multirow{2}{*}{$\begin{array}{c}\text { Standar } \\
\text { deviasi } \\
\text { (standard } \\
\text { deviation) }\end{array}$} & \multirow{2}{*}{$\mathbf{n}$} & \multicolumn{2}{|c|}{ Uji $\mathbf{t}$ (t test) } \\
\hline & & & & T hit & $T$ tabel $(\alpha, d b)$ \\
\hline $\begin{array}{l}\text { Berbasis Pengakuan Hak (recognice } \\
\text { customary right) }\end{array}$ & 2,883 & 0,971 & 24 & $-10,670$ & 1,713 \\
\hline Berbasis Dana (Money based) & 3,009 & 1,162 & 24 & $-8,387$ & 1,713 \\
\hline $\begin{array}{l}\text { Berbasis Pasar } \\
\text { ( market based) }\end{array}$ & 2,995 & 1,385 & 24 & $-7,084$ & 1,713 \\
\hline $\begin{array}{l}\text { Berbasis Barang } \\
\text { (goods based) }\end{array}$ & 3,562 & 1,088 & 24 & $-6,471$ & 1,713 \\
\hline $\begin{array}{l}\text { Berbasis Infrastruktur (Infrastructure } \\
\text { based) }\end{array}$ & 2,250 & 1,032 & 24 & $-13,053$ & 1,713 \\
\hline Berbasis Kelola Sosial (social based) & 2,578 & 1,319 & 24 & $-8,992$ & 1,713 \\
\hline $\begin{array}{l}\text { Berbasis Transfer IPTEK } \\
\text { (Transfer knowledge based) }\end{array}$ & 2,102 & 1,108 & 24 & $-12,805$ & 1,713 \\
\hline
\end{tabular}

hipotesis alaternatif yang diterima. Dengan demikian dapat dinyatakan bahwa skema pembagian manfaat bagi Suku Mairasi dengan pendekatan keamanan lebih kecil dari 3,68. Seluruh bentuk bagi manfaat berada dalam kisaran cukup atau sedang. Bila dilihat dari sebaran nilai rata-rata terdapat 2 bentuk yang masuk dalam kategori jelek atau rendah yakni bentuk berbasis infrastruktur $(2,250)$ dan berbasis transfer pengetahuan dan teknologi $(2,102)$. Terbukanya infrastruktur jalan disatu sisi memberikan kemudahan akses bagi masyarakat, namun saat yang bersamaan juga meningkatkan aktivitas perladangan berpindah masyarakat. Karena masyarat dapat mengakses wilayah berhutan yang jauh dari kampung dan membuka areal-areal baru bagi kegiatan perladangan. Selain itu, adanya pembukaan jalan menyebabkan masyarakat adat dengan mudah untuk melakukan perburuan dan pencaharian HHBK semakin jauh dari kampung. Akses jalan juga telah meningkatkan partisipasi masyarakat dalam hal pengelolaan, implementasi dan distribusi manfaat namun belum kapasitas masyarakat untuk terlibat dalam perencanaan dan pemeliharaan secara bersama-sama. Bentuk bagi manfaat ini juga tidak memberikan ruang bagi masyarakat adat untuk mengatur manfaat dari pengembangan infrastruktur terutama yang berkaitan dengan hak-hak masyarakat adat melalui lembaga adat yang mereka miliki.

Transfer pengetahuan dan teknologi diharapkan sebagai bagian dari upaya pemberdayaan karena akan membantu masyarakat dengan sumberdaya, kesempatan, keahlian dan pengetahuan untuk meningkatkan kapasitas sehingga dapat berpartsipasi untuk menentukan masa depan mereka. Namun hal tersebut tidak terwujud karena masyarakat tidak terlibat dalam pekerjaan yang membutuhkan keahlian kecuali buruh kasar. Sementara pekerjaan sebagai operator alat berat atau helper masyarakat tidak mendapat kesempatan. Hanya sebagian kecil yang terlibat sebagai anggota regu survei dalam kegiatan inventarisasi tegakan sebelum penebangan (ITSP).

\section{KESIMPULAN}

Bentuk pembagian manfaat dalam pengelolaan hutan produksi di wilayah adat Suku Mairasi Kabupaten Kaimana Provinsi Papua Barat terdiri dari pengakuan hak petuanan, berbasis dana, berbasis pasar, berbasis barang, berbasis infrastruktur, berbasis kelola sosialdan berbasis transfer ilmu pengetahuan dan teknologi. Pengembangan kriteria dari perspektif emik masyarakat adat menghasilkan 7 kritieria keadilan dan 6 kriteria keamanan yang kemudian digunakan untuk mengevaluasi kinerja bentu-bentuk pembagian manfaat tersebut. Penilaian dan pengujian kriteria tersebut terhadap berbagai bentuk pembagian manfaat baik pendekatan keadilan maupun keamanan berada dalam kategori cukup. Meskipun demikian masih terdapat bentuk pembagian manfaat yang memiliki nilai 
jelek atau buruk. Persoalan pembagian manfaat sekalipun merupakan komponen kecil dalam pengelolaan hutan produksi lestari tetapi dapat memperluas penerapan pendekatan keadilan dan keamanan sumberdaya hutan untuk menilai kinerja pengelolaan hutan pada unit manajemen.

Berdasarkan analisis kriteria dari perspektif emik, maka kriteria pendekatan keadilan dan keamanan berbasis masyarakat adat dapat digunakan untuk membentuk Norma, Standar, Prosedur dan Kriteria (NSPK) pengusahaan hutan produksi khususnya dalam pembagian manfaat. Bagi investor kehutanan perlu peningkatan kapasitas masyarakat adat sebagai tenaga-tenaga teknis kehutanan dengan training dan pendidikan sehingga menghasilkan tenaga teknis yang kompeten dan memenuhi syarat pasar tenaga kerja sektor kehutanan.

\section{UCAPAN TERIMA KASIH}

Penulis mengucapkan terima kasih kepada Pemerintah Kabupaten Kaimana cq. Dinas Kehutanan Kaimana atas fasilitasi yang diberikan dan dukungan data, masyarakat Kampung Kensi, Maskur, dan Urisa serta aparat kampung. Selain itu, ucapan terima kasih juga diberikan kepada Kepala Pusat Penelitian Lingkungan Hidup Univeritas Papua atas donasi penelitian.

\section{Daftar Pustaka}

Abu-Tapanjeh, M. (2006). Good Corporate Governance Mechanism and Firms' Operating and Financial Performance: Insight from the Perspective of Jordanian Industrial Companies. Journal of King Saud University, 19(2), 101-121. https:// www.semanticscholar.org/paper/Goodcorporate-governance-Mechanism-andFirms'-and-Abu-Tapanjeh/9ae6dba02ac5f a392ab9a379df560d7ddfb25e18

Baker, M., Clausen, R., Kanaan, R., N'Goma, M., Roule, T., \& Thomson, J. (2003). Conflict Timber:Dimensions of the Problemin Asia and Africa (Under the Biodiversity and Sustainable Forestry (BIOFOR) IQC; No. LAG-I-00-99-00013-00). https://inspectionpanel.org/sites/ inspectionpanel.org/files / ip / PanelCases/37-Request for Inspection Annex 25.pdf
Brito, B., Micol, L., Davis, C., Nakhooda, S., Daviet, F., \& Thuault, A. (2009). The Governance of Forests Toolkit (Version1): A draft Framework of Indicators for Assessing Governance of the Forest Sector. https:// pdf.wri.org/working_papers/gfi_tenure_ indicators_sep09.pdf

Bruce, J. W., \& Nielsen, R. (2012). Identifying and Working with Beneficiaries When Rights Are Unclear: Insights for REDD+ Initiatives (No. 71577; February 2012). https://openknowledge.worldbank.org/ handle/10986/12621

Dwiprabowo, H., \& Suwarno, E. (2013). Komponen dan Bobot dari Kriteria dan Indikator Tata Kelola Perusahaan Kehutanan. Jurnal Analisis Kebijakan Kehutanan, 10(2), 118-133. https://www. academia.edu/download/53007146/5j._ Komponen_Kriteria_dan_Bobot_GCG_ Kehutanan.pdf

Essam Yassin Mohammed. (2011). Propoor benefit distribution in REDD+: Who gets what and why does it matter? (No. 16508IIED; Economics, Monitoring, Evaluation and Learning). https://pubs. iied.org/16508IIED/

Grafton, R. Q., Squires, D., \& Fox, K. J. (2000). Private Property and Economic Efficiency: A Study of a Common-Pool Resource. The Journal of Law and Economics, 43(2), 679714. https://doi.org/10.1086/467469

IUCN. (2009). REDD-plus and Benefit sharing: Experiences in Forest Conservation and Other Resource Management Sectors (pp. 1-8). IUCN, Forest Conservation Programme. https://portals.iucn.org/ library/node/9498

Ja'far, M. (2007). Infrastruktur Pro Rakyat: Strategi Investasi Infrastruktur Indonesia Abad 21. Pustaka Tokoh Bangsa, LKiS.

LEI. (2006). Pedoman Pengambilan Keputusan Sertifikasi Pengelolaan Hutan Berbasis Masyarakat Lestari (PHBML). Lembaga Ekolabel Indonesia (LEI). https://lei.or.id/ phbml/

Lescuyer, G., Assembe Mvondo, S., Essoungou, J. N., Toison, V., Trébuchon, J.-F., \& Fauvet, N. (2012). Logging Concessions and Local Livelihoods in Cameroon: from Indifference to Alliance? Ecology and Society, 17(1), 1-13/art7. https://doi. org/10.5751/ES-04507-170107 
Michelle Maiese. (2013). Distributive Justice. Beyond Intractability. https:// www.beyondintractability.org/essay/ distributive_justice

Nawir, A. A., Paudel, N. S., Wong, G., \& Luttrell, C. (2015). Thinking about REDD+ benefit sharing mechanism (BSM): Lessons from community forestry (CF) in Nepal and Indonesia. $\quad$ https://doi.org/10.17528/ cifor/005506

Rahmawati, R. (2013). Konflik-konflik Sumberdaya Hutan di Jawa Barat dan Kalimantan Barat, Indonesia [Institute Pertanian Bogor]. https://docplayer. info/63999925-Konflik-konfliksumberdaya-hutan-di-jawa-baratdan-kalimantan-barat-indonesia-ritarahmawati.html

Sardjono, M. A. (2004). Mosaik Sosiologis Kehutanan: Masyarakat Lokal, Politik dan Kelestarian Sumber Daya (U. M. Ford Foundation, Melbourne Institute of Asian Languages and Societies (ed.)). Debut Press.

Schlager, E., \& Ostrom, E. (1992). PropertyRights Regimes and Natural Resources: A ConceptualAnalysis.LandEconomics,68(3), 249. https://doi.org/10.2307/3146375
Tokede, M. J., Wiliam, D., McGrath, S., \& Gandhi, O. (2005). Akses Masyarakat Adat terhadap Peluang-Peluang Pembangunan Kehutanan di Kabupaten Manokwari (No. 8; decentrali, CIFOR Decentralization Brief). Center for International Forestry Research (CIFOR). https://doi.org/10.17528/cifor/001692

Törnblom, K. Y., \& Vermunt, R. (2007). Towards an integration of distributive justice, procedural justice, and social resource theories. Social Justice Research, 20(3), 312-335. https://doi.org/10.1007/ s11211-007-0054-8

Wagstaff, G. F. (1994). Equity, equality, and need: Three principles of justice or one? An analysis of "equity as desert." Current Psychology, 13(2), 138-152. https://doi. org/10.1007/BF02686797

Wulan, Y. C., Yasmi, Y., Purba, C., \& Wollenberg, E. (2004). Analisa Konflik Sektor Kehutanan di Indonesia 1997-2003. CIFOR.

Yeny, I., \& Innah, H. S. (2014). Kajian Pelaksanaan Pembinaan Masyarakat Desa Hutan (PMDH) di Papua. Jurnal Penelitian Sosial Dan Ekonomi Kehutanan, 4(1), 73-91. http://garuda.ristekdikti.go.id/ documents/detail/772891 